\title{
COMPARATIVE STUDY OF INTERLOCKING AND SANDCRETE BLOCKS FOR BUILDING WALLING SYSTEMS
}

\author{
Sampson Assiamah ${ }^{1}$, Herbert Abeka ${ }^{2}$, Stephen Agyeman ${ }^{3}$ \\ ${ }^{1}$ Lecturer, Department of Building Technology, Sunyani Polytechnic, Sunyani, Ghana. \\ ${ }^{2,3}$ Lecturers, Department of Civil Engineering, Sunyani Polytechnic, Sunyani, Ghana. \\ assiamahs9@hotmail.com, herbertabeka@gmail.com,agyengo44@gmail.com
}

\begin{abstract}
The high cost of building materials, especially sandcrete blocks in Ghana, has made building construction products expensive and created a housing deficit of about 1.6 million. Meanwhile, the interlocking blocks, which are made up of laterite and cement abound could be exploited to help reduce the cost of housing construction. Especially, wall construction which is one of the major components of the entire building process. This paper sought to explore the possibility of adopting the interlocking block wall system as a means of making wall construction of buildings affordable in Ghana. A comparative study using interlocking blocks system and sandcrete blocks was made. An observation of the processes were made to identify the extent to which each system falls in line. A sample size of 45 respondents comprising 20 workers of P-A Capital Estate Housing, 5 personnel from consultancy firms and 20 private individuals were selected for further confirmatory study with the use of convenience and purposive sampling technique. To determine whether there were any statistically significant differences between the mean values, paired-sample t-test at the 0.05 level of significance was done. Results showed that, the use of interlocking blocks do not only lead to elimination of a number of non-value adding activities associated with the use of the sandcrete blocks, but also make the wall construction process cheaper and faster. It was also discovered that the absence of mortar jointing in the interlocking system reduced the quantity of materials, like cement and sand, required in the sandcrete wall construction process. Furthermore, there was no statistically difference between the compressive strength of interlocking blocks and conventional sandcrete blocks. However, there were statistically significant differences between construction cost and speed of construction using the two systems of construction.
\end{abstract}

KeyWords: walling systems, interlocking blocks, sandcrete blocks, non-value adding steps, construction speed and cost

\section{INTRODUCTION}

Interlocking compressed earth block (ICEB) masonry has the propensity to provide affordable and sustainable construction around the world [1, 2, 3, 4, 5]. Comprised basic inexpensive materials, such as laterite, the blocks can provide homes and other facilities at low cost $[6,7]$. By creating interlocking joints between layers of blocks, ICEBs allow for the blocks to be dry stacked, without the need for mortar [8].

Soil has been used as a building material for thousands of years (almost $30 \%$ of world's present population still lives in laterite or soil structures). Adobe, rammed earth, and compressed earth masonry are examples of tradition building materials in today's world [9]. Using soil as the main material component of a building provides benefits such as the use of local materials, high thermal mass values and increased workability $[10,11]$. Laterite is affordable, environmentally friendly and plentifully available building material in the tropical regions $[12,13]$.

Lately, dry stacking or mortarless technology is increasingly becoming popular. [14] stated that, conventional masonry is losing grounds to dry-stacking technology. The clients are influenced by the merits they frequently perceive in these new systems which include lower installed costs, shorter site time and dependence on a small pool of highly skilled labor. Also, the elimination of the non-value adding activities [15] associated with design and construction processes results in minimal waste generation [16]. However, conventional masonry relatively requires more labor hours, highly skilled and highly paid workers. Laying the first course in the mortar bed requires that care is taken to ensure that blocks are impeccably horizontal and in a straight line or rightangled at corners. Once the base is properly laid, the blocks are stacked dry with the assistance of a wooden rubber hammer to knock the blocks gently in place [17].

The building construction industry in Ghana, particularly the urban housing sector, is subjugated by the use of the sandcrete blocks for wall construction [18]. Various forms of waste in terms of time, energy and financial costs have however been observed to be linked with the process of erecting walls by this walling system [19, 20, 9]. Buildings are the major energy consumers and greenhouse gases emitters worldwide, consuming above $50 \%$ in most cases [8]. [21], opined that walling materials in any building contribute about $22 \%$ of the total building cost. The selection of a walling materials is centered on a number of factors such as; cost, durability, aesthetics and ability to withstand the immediate environmental conditions $[9,21]$. 
Also, [22] and [23], stated that building materials form the key factors that limit the supply of housing and established that they account for between 50 to $70 \%$ of the cost of buildings. These have led to the need to explore the possibility of adopting other walling systems like ICEB wall in order to reduce waste and maximize value. More importantly, the present system does a little to support the sustainable construction agenda.

The paper aimed at comparing the speed, material (mortar) and labor savings using interlocking blocks and sandcrete blocks for the construction of walling units in Ghana. The study also sought to identify how the interlocking blocks concept can be successfully incorporated into the housing sector of the country and to provide additional support (if not a good alternative) to the affordable housing pursuit in Ghana. The essence is to justify the concept as contributing to the sustainable construction agenda.

\subsection{Research Questions}

1. What is the difference in speed of construction between interlocking blocks and sandcrete blocks?

2. Is there any difference in the cost of labor for constructing a wall using interlocking blocks and sandcrete blocks?

3. What is the difference in the total construction cost between interlocking blocks and sandcrete blocks?

4. What is the difference in compressive strength between interlocking blocks and sandcrete blocks?

\section{MATERIAL COMPOSITION OF INTERLOCKING BLOCKS}

\subsection{Laterite}

Different kinds of materials are used for the design and construction of walls in buildings including sand, laterite, timber, glass, plastic etc., in Ghana. Laterite forms a greater percentage of the land surface or soil composition in the country and hence is more available and least expensive than any of the above-mentioned building materials. It is estimated that about $70 \%$ of Ghana's land surface is covered by laterite [24]. The lateritic clay soil used in the study was obtained from a borrow pit in Sunyani, Ghana between a depth of $1.0 \mathrm{~m}$ to $1.5 \mathrm{~m}$ via method of disturbed sampling.

\subsection{Cement}

As a stabilizing material cement is well researched, well understood and its properties clearly defined [25]. Portland cement is readily available in almost all Urban and Semiurban areas, it is one of the major components for any building construction [26]. Earlier studies have shown that cement is a suitable stabilizer for use with soil in the production of Cement Stabilized Soil Block (CSSB) [7, 27]. The cement used was GHACEM (Ghana Cement) an Ordinary Portland Cement (OPC) procured from a cement depot in Sunyani, Ghana.

\subsection{Water}

Water used for the study was clean and does not contain any harmful quantities of acid, alkalis, salts, sugar or any other organic or chemical material. Because any organic material in water would have prevented the cement from setting. Chemicals and impurities could also have affected the strength of the end product.

\section{METHODS AND MATERIALS}

\subsection{Description of the Area of Study}

The study involved a comparative study of the processes involved in constructing L-walls with sandcrete blocks and interlocking blocks using field observations and battery of laboratory tests. A critical observation of the various steps involved in using the sandcrete blocks and the interlocking blocks in wall construction was made. This made it possible to make a comparison of the non-value adding steps associated with sandcrete block wall construction to those associated with interlocking block wall construction. The speed of construction, compressive strength and the costs of constructing the walls were then estimated and compared.

\subsection{Data Collection Methods}

For the purpose of getting valid, reliable, adequate and current information, the researchers resorted to the use of primary research. This approach was used because of the high percentage of illiterates in the building construction industry within the Sunyani municipality. The instruments used for collecting the primary data were:

- Experimentals and observations.

- Questionnaires.

\subsubsection{Experimentals and Observation Procedures}

Work study methods were used to provide a ground for comparison between the sandcrete block and the interlocking block units in case of cost effectiveness, economy and functionality. This method was employed to obtain firsthand information on both practices under study.

The process involved the manufacturing of solid sandcrete blocks of dimensions $450 \mathrm{~mm} \times 100 \mathrm{~mm} \times 225 \mathrm{~mm}$ and $240 \mathrm{~mm} \times 230 \mathrm{~mm} \times 115 \mathrm{~mm}$. Sand was used with OPC with clean potable water to mix the sandcrete ingredients on the ratio of 1 part cement to 9 parts of sand (1:9 cement-sand ratio). While laterite and sand were used with OPC and clean potable water (water-cement ratio was 0.6) to mix the interlocking ingredients on ratio of 1 head-pan of cement to 2 head-pans of sand to 7 head-pans of laterite (1:2:7 cementsand-laterite ratio). The addition of sand to the cement and the laterite was to increase the strength of the interlocking blocks because of its fine particles. Laterite contains rough particles, therefore the sand comes in so that the pores can be filled well for easy compaction to give high densities and strengths. But cement-sand mix reduces strength than cement-sand-laterite mix because there is no rough particles in it like gravels in the former case. 
The batching was done by volume of standard head pan of $0.015 \mathrm{~m}^{3}$. Mixing was done by hand, using shovel, before molding using hand operated block molding machine and interlocking block molding machine. The units were moist cured by wetting after the initial setting until sufficient strength is gained and their compressive strengths determined at 7, 14 and 28 days periods. The average weights of each set of blocks were calculated by weighing 50 randomly selected blocks.

The observational data for the study was obtained by engaging masons in the construction of two sets of walls using sandcrete blocks and interlocking blocks. Each unit comprised L-shaped wall measuring $3200 \mathrm{~mm}$ x $600 \mathrm{~mm}$ as shown in Figs 1(a) and 1(b).

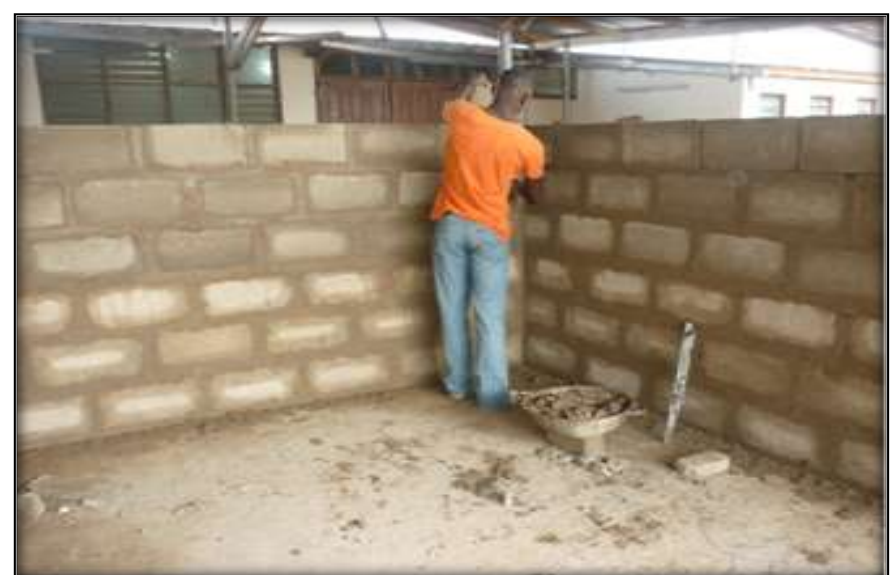

Fig - 1 (a): Sandcrete block wall

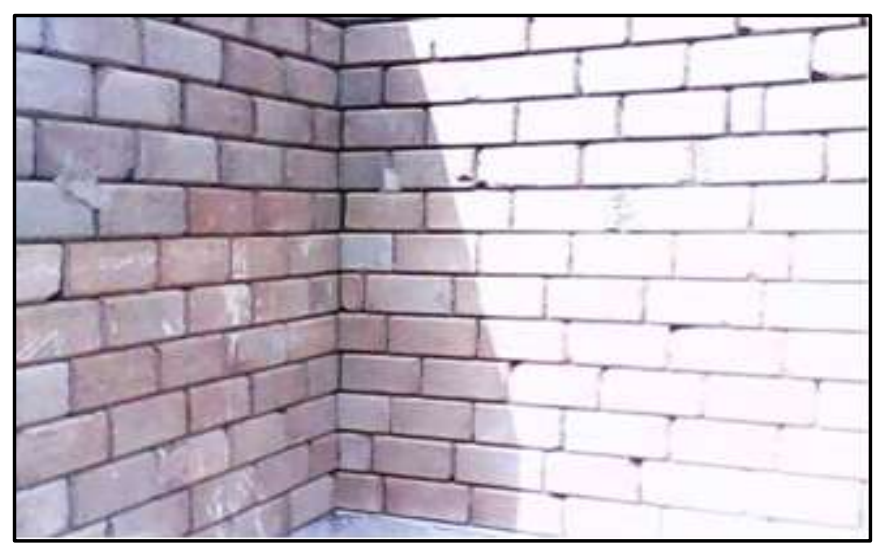

Fig - 1(b): Interlocking block wall

Two masons, $\mathrm{X}$ and $\mathrm{Y}$ both skilled in sandcrete block wall construction and interlocking block wall construction were engaged in the process.

The first part involved a simultaneous process whereby mason $X$ constructed one set of the walls from the sandcrete blocks, while mason $\mathrm{Y}$ constructed the other set of wall with interlocking blocks. The second part of the experiment was a reverse of the first in which case mason $X$ rather constructed the wall with interlocking blocks while mason $\mathrm{Y}$ constructed the wall with sandcrete blocks.
During each part of the experiment observations were made of the comparative speed of construction between the use of interlocking blocks and sandcrete blocks. Various forms and sources of waste arising from the use of the sandcrete blocks were also observed and compared to those arising from the use of the interlocking blocks.

Compressive strengths for the two block types were also determined using a compressive testing machine as shown in Fig 2.

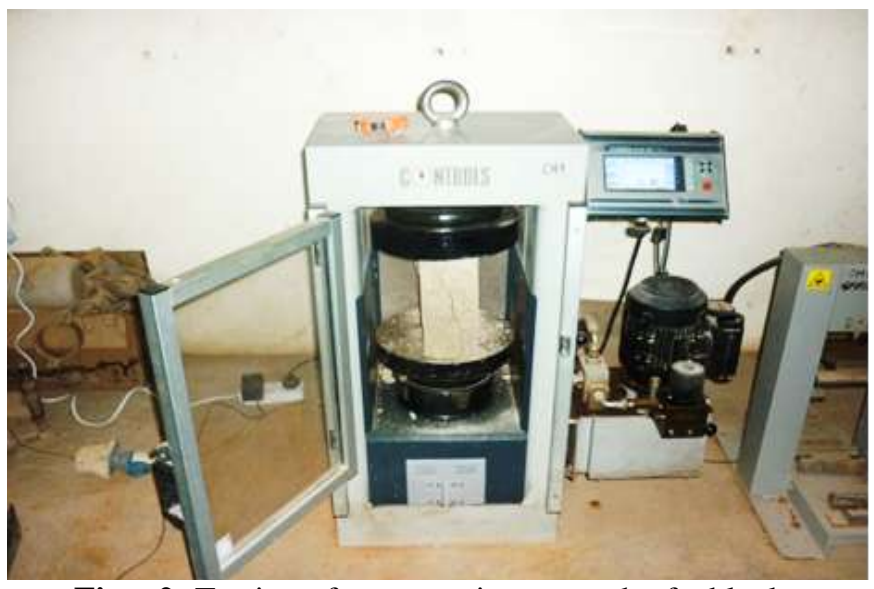

Fig - 2: Testing of compressive strength of a block

The compression tests were done in 3 batches to determine the compressive strengths of both the interlocking blocks and the sandcrete blocks. The 1 st batch was cured for 7 days, 2nd batch for 14 days and 3rd for batch 28 days. Thereafter, 10 blocks were randomly sampled from each batch of blocks for testing to determine their compressive strengths.

One of the key limitations in the data collection procedure was the fact that unlike the interlocking block system, it was not possible to build a continuous height of wall above $1400 \mathrm{~mm}$ with the sandcrete block without allowing the wall to dry and harden to prevent a collapse. This situation limited the study to a wall height of $1400 \mathrm{~mm}$.

\subsubsection{Questionnaires Survey}

Three different sets of questionnaires were prepared, each for personnel of consultancy firms, staff of P-A capital Estate Housing and private individuals. The distribution of the questionnaires was done through personal visit to firms and project sites as mailing services were not applicable in most instances. Again, it afforded the researchers the opportunity to establish strong rapport with the respondents. The questionnaire items were designed with both close ended questions where a respondent was required to choose from a list of options or answers provided to respond to a question and open ended items in which the respondent provided the answers. A sample size of 45 respondents comprising 20 workers of P-Capital Estate Housing, 5 personnel from consultancy firms and 20 private individuals were selected for the study with the use of convenience and purposive sampling technique. With this sampling 
technique, the researchers selected the easily accessible population members from whom to obtain information.
Table 1 shows the steps involved in the construction of the sandcrete wall and the interlocking wall.

\section{RESULTS AND DISCUSSION}

\subsection{Steps Involved in Two-Wall Construction}

Table -1: Steps involved in walls construction

\begin{tabular}{|c|c|c|c|c|}
\hline Stage & Description & Activities (Steps) & $\begin{array}{l}\text { Sandcrete } \\
\text { Block Walling }\end{array}$ & $\begin{array}{l}\text { Interlocking } \\
\text { Block Walling }\end{array}$ \\
\hline \multirow{2}{*}{ A } & \multirow{2}{*}{$\begin{array}{l}\text { General (Preliminary) } \\
\text { Preparation }\end{array}$} & A1. Setting out & $\bullet$ & $\bullet$ \\
\hline & & A2. Preparation of mortar & $\bullet$ & $\bullet$ \\
\hline \multirow{7}{*}{ B } & \multirow{7}{*}{ Laying First Course } & B1. Transporting mortar & $\bullet$ & $\bullet$ \\
\hline & & B2. Spreading base mortar & $\bullet$ & $\bullet$ \\
\hline & & B3. Transporting block units & $\bullet$ & $\bullet$ \\
\hline & & B4. Placing block units in first course & $\bullet$ & $\bullet$ \\
\hline & & B5. Plumbing & $\bullet$ & $\bullet$ \\
\hline & & B6. Levelling & $\bullet$ & $\bullet$ \\
\hline & & B7. Filling and dressing vertical mortar joints & $\bullet$ & ○ \\
\hline \multirow{7}{*}{$\mathrm{C}$} & \multirow{7}{*}{ Laying Subsequent Courses } & C1. Transporting mortar & $\bullet$ & ○ \\
\hline & & C2. Spreading mortar for the course & $\bullet$ & $\circ$ \\
\hline & & C3. Transporting block units & $\bullet$ & $\bullet$ \\
\hline & & C4. Placing block units in the course & $\bullet$ & $\bullet$ \\
\hline & & C5. Plumbing & $\bullet$ & $\bullet$ \\
\hline & & C6. Levelling & $\bullet$ & ○ \\
\hline & & C7. Filling and dressing vertical mortar joints & - & $\circ$ \\
\hline
\end{tabular}

\section{Legend:}

- Applicable step

$\circ$ Eliminated / non-value adding step

\subsection{Speed of Construction}

For the interlocking block walling system, there were 5 nonvalue adding steps in stages $\mathrm{B}$ and $\mathrm{C}$ which include: $\mathrm{B} 7-$ Filling and dressing vertical mortar joints, C1-Transporting mortar, C2-Spreading mortar for the course, C6-Levelling and C7-Filling and dressing vertical mortar joints. These non-value adding steps were eliminated after laying the base of the interlocking block wall. However, all the steps from A1 to $\mathrm{C} 7$ in Table 1 were applied during the sandcrete wall construction process. Though, more blocks are required in the case of the interlocking block wall, mortar usage was less. The times spent to undertake the various activities in the construction of the two walling systems are shown in Table 2.

\subsubsection{Completion of first course}

During the construction of the first course of the two walling systems, it took mason X 21 minutes to complete the sandcrete block wall and 27 minutes to complete interlocking block wall. Mason Y used 20 minutes to complete the sandcrete block wall and 28 minutes to complete the interlocking block wall. The time that was spent in the construction of the first course of the interlocking block wall across all the various phases of the study was generally more than the time spent in the construction of the first course of the sandcrete block wall. Averagely, $33 \%$ of the total time used for constructing the interlocking wall was spent in completing the first course. The relatively more time spent in the construction of the first course of the interlocking wall resulted from more time spent in plumbing and levelling the first course to achieve a near perfect alignment in order to avoid coordination problems during the dry bonding (locking of blocks) for subsequent courses. 
Table -2: Times used by mason $\mathrm{X}$ and $\mathrm{Y}$ for the wall construction

\begin{tabular}{llllll}
\hline Technique & Mason & $\begin{array}{l}\mathbf{1}^{\text {st }} \text { Course } \\
\text { (minutes) }\end{array}$ & $\begin{array}{l}\mathbf{2}^{\text {nd }} \text { Course } \\
\text { (minutes) }\end{array}$ & $\begin{array}{l}\text { Subsequent } \\
\text { Courses } \\
\text { (minutes) }\end{array}$ & $\begin{array}{l}\text { Entire wall } \\
\text { (minutes) }\end{array}$ \\
\hline Sandcrete block & $\mathrm{X}$ & 21 & 23 & 133 & 177 \\
& $\mathrm{Y}$ & 20 & 21 & 135 & 176 \\
Interlocking block & $\mathrm{X}$ & 27 & 5 & 52 & 84 \\
& $\mathrm{Y}$ & 28 & 5 & 52 & 85 \\
\hline
\end{tabular}

\subsubsection{Completion of second course}

In completing the second course, it took mason $X 23$ minutes to construct the sandcrete block wall while mason $\mathrm{Y}$ used 21 minutes to do same. Also, both masons completed their respective interlocking block walls in 5 minutes.

\subsubsection{Completion of subsequent courses}

Mason X used a total of 2 hours 13 minutes in the construction of the subsequent courses of the sandcrete block wall and 52 minutes for the interlocking block wall. Similarly, mason $\mathrm{Y}$ used 2 hours 15 minutes for constructing the sandcrete block wall and 52 minutes for the interlocking block wall.

\subsubsection{Completion of the entire wall}

In constructing the entire wall, mason $\mathrm{X}$ used a total of 2 hours 57 minutes while mason Y used 2 hour 56 minutes for the sandcrete wall. Mason $\mathrm{X}$ used a total of 1 hour 24 minutes for constructing the interlocking block wall whereas mason $\mathrm{Y}$ trailed $\mathrm{X}$ by 1 minute in the interlocking block wall construction process. On the average, both masons completed the sandcrete wall in 2 hours 56 minutes 30 seconds and 1 hour 24 minutes 30 seconds for the sandcrete and interlocking block walls respectively. There was total average time savings of 1 hour 32 minutes (176.5-84.5 minutes) in using the interlocking blocks as the wall height increased (after the first course wall construction). Because there was no need to do filling and dressing of the vertical mortar joints as is required in conventional sandcrete block walling systems. Archetypally, a mason constructing Lshape wall of height $1400 \mathrm{~mm}$ using interlocking blocks is 2 times faster than using sandcrete blocks. It is therefore speedier using interlocking blocks for wall construction though more time was spent in building the first course.

Speedy delivery is very important to meet the duration of every construction. The delivery of construction products on time, apart from contributing to a reduction in cost of construction, also enhances value to clients. With little computations it can be deduced that for the first course, the sandcrete block wall was constructed at an average speed of 1.34 times faster than the interlocking. For the other courses, interlocking block wall was constructed at an average speed of 4.40 times faster than the sandcrete for the second course, 2.58 faster for the subsequent courses after the first, and 2.09 faster for the completion of the entire wall. These indicate that the pace of wall construction using the interlocking blocks is always faster than using the sandcrete block. The elimination of non-value steps like spreading mortar, levelling, and vertical mortar jointing and dressing of joints significantly reduced the cycle time of bonding blocks thus increasing the speed of the wall construction.

Close to $70 \%$ of the respondents (users) confirmed the high speed of construction using interlocking blocks which may be due to their interlocking ability compared with the $30 \%$ rate for sandcrete blocks.

\subsection{Labor Cost}

Table 3 contains the cost associated with the process of constructing a wall with the interlocking blocks and the conventional sandcrete blocks. Labor cost was calculated at a rate of $\mathrm{Gh} \phi 5.00 / \mathrm{hr}$. and material cost at a rate of $\mathrm{Gh} \varnothing 400.00 / \mathrm{m}^{3}$ of mortar.

The average time spent per mason for building the first course of sandcrete block wall was 0.35 hour at a cost of Ghø1.75 and that of the interlocking block wall was 0.46 hour at a cost of Ghф2.30. The average time spent per mason for spreading mortar of the subsequent courses for sandcrete block wall was 0.54 hour at a cost of Ghф2.70. The average time spent per mason for placing blocks, levelling and plumbing for sandcrete block wall was 1.10 hours at a cost of Ghф5.50 and that of the interlocking block wall was 0.95 hour at a cost of Ghф4.75. The average time spent per mason for filling and dressing the vertical joints for sandcrete block wall was 0.95 hour at a cost of Ghф4.75. The non-value adding activities in the interlocking wall construction process of spreading mortar for subsequent courses and filling and dressing vertical mortar joints were excluded in the labor cost build up. The total labor cost for the entire sandcrete block wall was $\mathrm{GH} \phi 14.70$ for a total time of 2.94 hours and that of the interlocking block wall was $\mathrm{GH} \not 7.05$ for a total time of 1.41 hours.

The mortarless interlocking construction was "lean" because it used less of everything including labor [28]. The study showed that greater outputs of masons are always achieved in the use of the interlocking block system compared to the sandcrete block system. The output of masons increased more than $50 \%$ when they used the interlocking blocks than sandcrete blocks. The higher output of the masons resulted from the fact that some steps were eliminated in using the interlocking blocks compared to when laying with the traditional sandcrete blocks. The incidence of "waiting" resulting from the disjointed stop-and-go production 
processes associated with the sandcrete blocks, was also largely reduced in the case of the interlocking blocks therefore increasing productivity. The idle time of labor in the use of the interlocking block compared to the sandcrete block was also drastically reduced. Unlike the sandcrete block walling system, the continuous workflow nature of the interlocking block walling system took away the intermittent idle times particularly associated with laborers who were engaged to carry blocks and mortar for jointing. The wall construction steps of spreading mortar, vertical jointing, mortar joint dressing and levelling led to the labor idle time in the use of the sandcrete blocks.

Table - 3: Cost of wall construction

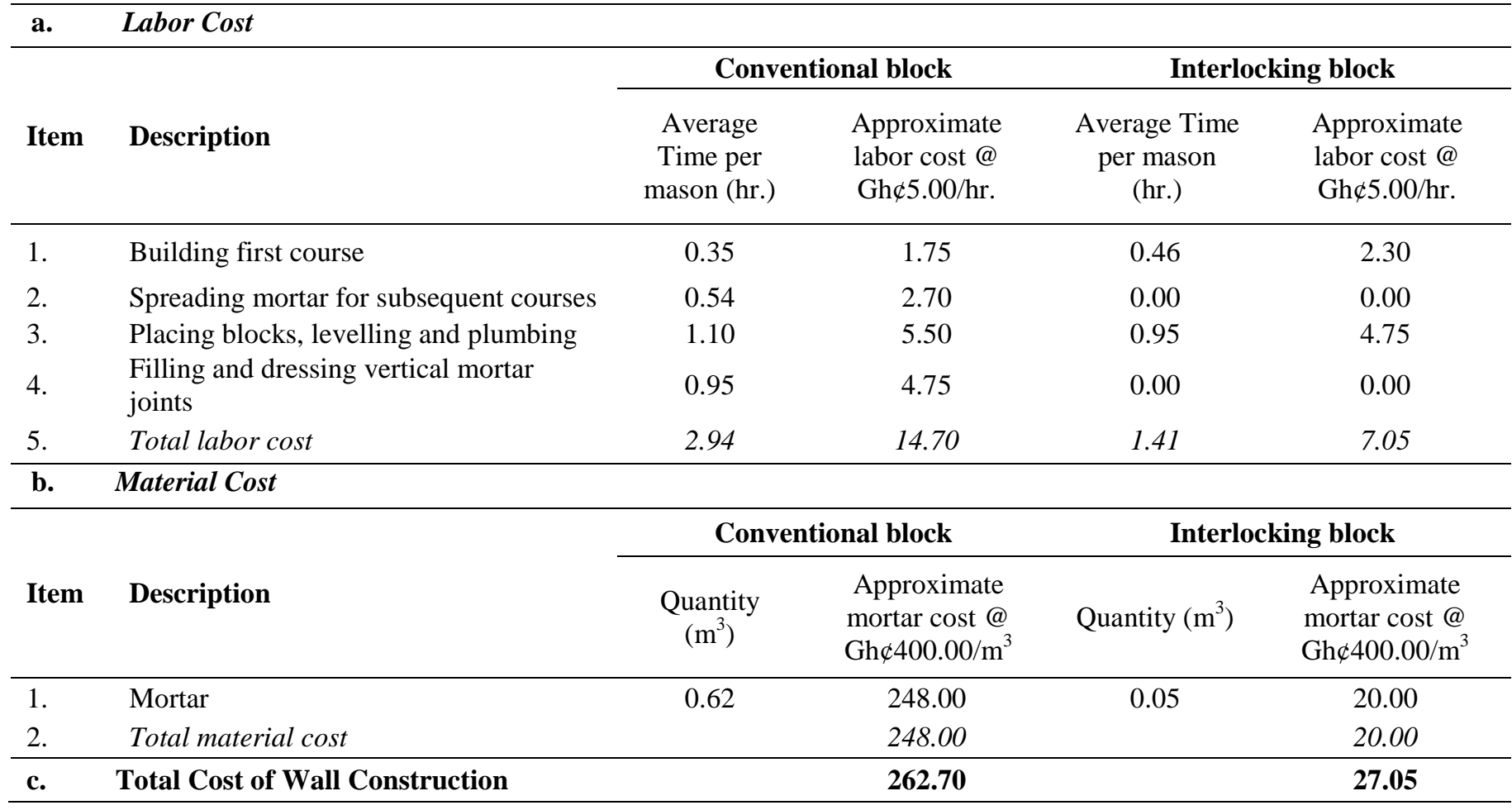

\subsection{Material Cost}

Apart from the base mortar that is required to link the first course to the floor, virtually no mortar is required for the subsequent courses of the interlocking walling system. The absence of mortar jointing in the interlocking block walling process led to a significant reduction in the quantity of mortar used compared to the case of the sandcrete block. This assertion was confirmed by field simulation outcomes in Table 3. The total cost of materials for the entire sandcrete block wall was $\mathrm{GH} \phi 248.00$ for $0.62 \mathrm{~m}^{3}$ of mortar and that of the interlocking block wall was $\mathrm{GH} \phi 20.00$ for $0.05 \mathrm{~m}^{3}$ of mortar. The results revealed that the average material (mortar in this case) usage per mason or both masons was far less for the interlocking block wall than the sandcrete block wall. The insignificant role of mortar in the interlocking block walling process implies that materials like fine aggregate and cement are scarcely required in the wall construction process. This ensures that inventory and space associated with the wall construction process were reduced to a significant level.

\subsection{Cost of Construction Wall}

The cost of every construction process is mainly influenced by inputs like materials and labor. Any attempt at reducing the cost of these two inputs will go a long way to reduce the overall cost of any construction process [23]. The use of the interlocking block resulted in significantly reducing requirements for labor and material of the wall construction process compared to the use of the sandcrete block. This situation led to a lesser cost of constructing the wall with the interlocking block relative to using the traditional sandcrete block. The overall cost as shown in Table 3 of constructing the sandcrete block wall was $\mathrm{GH} \notin 262.70$ and that of the interlocking block wall was $\mathrm{GH} \notin 27.05$. Also, the unit cost of interlocking block currently is $\mathrm{GH} \phi 1.20$ per block while the sandcrete block is GH $₫ 3.00$ per block. Therefore, the interlocking block is cheaper than the sandcrete block on the market. Between the two cost parameters of labor and materials, the relatively lesser cost of construction of the interlocking block wall was driven more by the reduction in the use of materials in the form of mortar. It was the less used of mortar for jointing which largely contributed to a reduction in the cost of interlocking block wall construction process by about $91 \%$ compared to the sandcrete block. 


\subsection{Compressive Strength Test Results}

It was observed that even though the weights of $115 \mathrm{~mm}$ thick interlocking block units were on the average $60 \%$ that of $100 \mathrm{~mm}$ thick sandcrete units, their compressive strengths taken unit by unit were higher than those of $100 \mathrm{~mm}$ thick sandcrete units. On the average however, there was a difference of $0.04 \mathrm{~N} / \mathrm{mm}^{2}$ which meant that the average compressive strength of $100 \mathrm{~mm}$ sandcrete unit was $98 \%$ of that of $115 \mathrm{~mm}$ thick interlocking unit. Though there were differences in the weight of the sandcrete blocks and interlocking blocks, their compressive strengths were almost the same.

The compressive strengths tests of the $100 \mathrm{~mm}$ thick sandcrete block and $115 \mathrm{~mm}$ thick interlocking block at 7, 14 and 28 days curing periods are summarized in Table 4 .

Table -4: Compressive strength for sandcrete blocks and interlocking blocks

\begin{tabular}{lllll}
\hline \multirow{2}{*}{ Age } & \multicolumn{1}{l}{$\mathbf{1 0 0 \mathbf { m m }}$ Thick Sandcrete Block } & \multicolumn{2}{l}{$\mathbf{1 1 5} \mathbf{m m}$ Thick Interlocking Block } \\
\cline { 2 - 5 } & Mean $\left(\mathrm{N} / \mathrm{mm}^{2}\right)$ & Standard Deviation $\left(\mathrm{N} / \mathrm{mm}^{2}\right)$ & Mean $\left(\mathrm{N} / \mathrm{mm}^{2}\right)$ & Standard Deviation $\left(\mathrm{N} / \mathrm{mm}^{2}\right)$ \\
\hline 7 & 1.26 & 0.081 & 1.30 & 0.128 \\
14 & 1.98 & 0.203 & 2.02 & 0.116 \\
28 & 3.52 & 0.096 & 3.56 & 0.050 \\
\hline
\end{tabular}

For 7 days curing, the average strength of $100 \mathrm{~mm}$ thick sandcrete block was $1.26 \mathrm{~N} / \mathrm{mm}^{2}$ with the standard deviation of $\pm 0.081 \mathrm{~N} / \mathrm{mm}^{2}$ and the average strength of $115 \mathrm{~mm}$ thick interlocking block was $1.30 \mathrm{~N} / \mathrm{mm}^{2}$ with a standard deviation of $\pm 0.128 \mathrm{~N} / \mathrm{mm}^{2}$. For 14 days curing, the average strength of $100 \mathrm{~mm}$ thick sandcrete block was $1.98 \mathrm{~N} / \mathrm{mm}^{2}$ with a standard deviation of $\pm 0.203 \mathrm{~N} / \mathrm{mm}^{2}$ and the average strength of $115 \mathrm{~mm}$ thick interlocking block was $2.02 \mathrm{~N} / \mathrm{mm}^{2}$ with a standard deviation of $\pm 0.116 \mathrm{~N} / \mathrm{mm}^{2}$. For 28 days curing, the average strength of $100 \mathrm{~mm}$ thick sandcrete block was $3.52 \mathrm{~N} / \mathrm{mm}^{2}$ with a standard deviation of $\pm 0.096 \mathrm{~N} / \mathrm{mm}^{2}$ and the average strength of $115 \mathrm{~mm}$ thick interlocking block was $3.56 \mathrm{~N} / \mathrm{mm}^{2}$ with a standard deviation of $\pm 0.050 \mathrm{~N} / \mathrm{mm}^{2}$. In all the test cases, the interlocking blocks showed marginally higher strength than the conventional sandcrete blocks. Compressive strengths of the two block types increased with corresponding increased in aging.

\subsection{Hypothesis Testing}

The results of the paired-sample t-test used to estimate the significance between the interlocking blocks and conventional sandcrete blocks units with the help of SPSS (Statistical Package for Social Sciences) version 19 at significance level of 0.05 are shown in Table 5.

Notwithstanding the closeness of the mean values, it was deemed appropriate to determine whether there were any statistically significant differences between the values using paired-sample t-test at the 0.05 level of significance.

\section{Hypothesis 1 - Speed of construction}

Null Hypothesis $\left(H_{01}\right)$ : There is no significant difference between the speed of construction with interlocking block and speed of construction using conventional sandcrete block.
Alternative Hypothesis $\left(\mathrm{Ha}_{1}\right)$ : There is a significant difference between the speed of construction with interlocking block and speed of construction using conventional sandcrete block.

With t-value of 76.50 and significance of 0.008 , it can be concluded that there is statistically significant difference between the construction speed of interlocking blocks and conventional sandcrete blocks. The study therefore rejected the null hypothesis $\left(\mathrm{H}_{01}\right)$ and accepted the alternate hypothesis $\left(\mathrm{Ha}_{1}\right)$.

\section{Hypothesis 2 - Labor cost}

Null Hypothesis $\left(\mathrm{H}_{02}\right)$ : There is no significant difference between the labor cost of construction with interlocking block and conventional sandcrete block.

Alternative Hypothesis $\left(\mathrm{Ha}_{2}\right)$ : There is a significant difference between the labor cost of construction using interlocking block and conventional sandcrete block.

The results indicated that the t-value was 1.695 with significance level 0.189 . This results implied that there is no statistically significant difference between cost of labor (mason and laborer) using interlocking blocks and conventional sandcrete blocks. The study therefore assumed the null hypothesis $\left(\mathrm{H}_{02}\right)$.

\section{Hypothesis 3 - Construction cost}

Null Hypothesis $\left(H_{03}\right)$ : There is no significant difference between the cost of constructing the entire L-wall using interlocking blocks and conventional sandcrete blocks.

Alternative Hypothesis $\left(\mathrm{Ha}_{3}\right)$ : There is significant difference between the cost of constructing the entire L-wall using interlocking blocks and conventional sandcrete blocks. 
Table -5: Paired-sample t-test results

\begin{tabular}{|c|c|c|c|c|c|}
\hline Test Areas & $\begin{array}{l}\text { Sandcrete } \\
\text { Block }\end{array}$ & $\begin{array}{l}\text { Interlocking } \\
\text { Block }\end{array}$ & Difference & t-value & $\begin{array}{l}\text { t-test for significance } \\
\text { for the differences }\end{array}$ \\
\hline \multicolumn{6}{|l|}{ Construction Speed } \\
\hline 1 Mason X & 2.95 & 1.40 & 1.55 & \multirow{3}{*}{76.500} & \multirow{3}{*}{$0.008 *$} \\
\hline 2 Mason Y & 2.93 & 1.42 & 1.52 & & \\
\hline Total & 5.88 & 2.82 & & & \\
\hline \multicolumn{6}{|l|}{ Labor Cost } \\
\hline $11^{\mathrm{st}}$ course & 1.70 & 2.10 & -0.40 & \multirow{5}{*}{1.695} & \multirow{5}{*}{0.189} \\
\hline 2 Spreading mortar & 2.60 & 0.00 & 2.60 & & \\
\hline 3 Placing blocks & 5.50 & 4.75 & 0.75 & & \\
\hline 4 Filling \& dressing & 4.90 & 0.00 & 4.90 & & \\
\hline Total & 14.70 & 6.85 & & & \\
\hline \multicolumn{6}{|l|}{ Costs of Constructing Wall } \\
\hline Labor Cost & 14.70 & 6.85 & 7.85 & \multirow{3}{*}{59.089} & \multirow{3}{*}{$0.011^{*}$} \\
\hline Mortar (Material) Cost & 248.00 & 20.00 & 228 & & \\
\hline Total & 262.70 & 26.85 & & & \\
\hline \multicolumn{6}{|c|}{ Compressive Strength Test } \\
\hline 7 days & 1.26 & 1.30 & -0.04 & \multirow{4}{*}{-1.316} & \multirow{4}{*}{0.199} \\
\hline 14 days & 1.98 & 2.02 & -0.04 & & \\
\hline 28 days & 3.52 & 3.56 & -0.04 & & \\
\hline Total & 6.88 & 6.88 & & & \\
\hline
\end{tabular}

* Statistically significant at 0.05 level

The paired-sample t-test results at the 0.05 level of significance from Table 5 gave a t-value of 59.089 with significance level of 0.011 . This meant that there was statistically significant difference between the cost of constructing the L-wall using the interlocking blocks and conventional sandcrete blocks. The study therefore rejected the null hypothesis $\left(\mathrm{H}_{03}\right)$ and accepted the alternate hypothesis $\left(\mathrm{Ha}_{3}\right)$.

Hypothesis 4-Compressive strength

Null Hypothesis $\left(\mathrm{H}_{04}\right)$ : There is no significant difference between the compressive strength of interlocking blocks and conventional sandcrete blocks.

Alternative Hypothesis $\left(\mathrm{Ha}_{4}\right)$ : There is significant difference between the compressive strength of interlocking blocks and conventional sandcrete blocks.

The results from the paired-sample t-test shown in Table 5 at 0.05 level of significance, gave a t-value of -1.316 with significance level of 0.199 . Therefore, there was no statistically difference between the compressive strengths of interlocking blocks and conventional sandcrete blocks. The study therefore assumed the null hypothesis $\left(\mathrm{H}_{04}\right)$.

\subsection{Thermal Properties of Interlocking Blocks}

Results showed that $70 \%$ of the respondents used interlocking blocks because of their higher rate of coolness than sandcrete blocks with $30 \%$ believing the opposite. Confirming [29] conclusion that interlocking blocks are more effective in thermal resistance and make the interior part of the building (room) cooler than sandcrete blocks. According to [13] also, houses built with earth tend to be naturally cool in the summer heat and warm in winter weather.

\subsection{Affordability of blocks}

From users' perspective, interlocking blocks seemed affordable. According to the survey results, 70\% said interlocking blocks offered higher affordability than sandcrete blocks while $30 \%$ believed otherwise. [24], observed the difficulty of transporting sand over long distances for building purposes, the excessive exploitation and depletion of sand deposits in Ghana. Additionally, the exorbitant cost of sandcrete blocks as a result of the relative high cost of sand and indicated that lateritic materials should be exploited in the building industry to produce affordable and sustainable construction in Ghana.

\section{CONCLUSIONS}

The elimination of the various non-value adding steps associated with the conventional sandcrete block wall construction when using the interlocking block system significantly reduce the cycle time of block bonding thus increasing the speed of wall construction for interlocking blocks. Interlocking blocks are affordable in terms of cost and the ability to make the room cooler especially in hot weather conditions compared with sandcrete blocks. There is also a significant reduction in the material requirement for the interlocking block wall construction process due to the absence of mortar jointing. Reduction in the labor and material requirements in the interlocking block wall construction make the cost associated with the process of building walls using the interlocking blocks less expensive. 
The interlocking blocks have almost the same compressive strength as that of the sandcrete blocks.

The following specific conclusions are drawn from the statistical analysis:

1. There is significant difference between the interlocking blocks and conventional sandcrete blocks speed of construction. The interlocking blocks construction proved to be faster with better workability after laying the 1 st course thereby ensuring speedy construction.

2. There is no significant difference between the interlocking blocks and conventional sandcrete blocks cost of labor. This means that in terms of labor cost, the interlocking block wall construction is within the range of the conventional sandcrete block construction.

3. There is significant difference between the costs of constructing the entire L-wall using interlocking blocks and conventional sandcrete blocks. This suggest that interlocking blocks are affordable in favor of low cost constructions, especially in developing countries with high deposits of laterite.

4. There is no significant difference between compressive strength of interlocking blocks and conventional sandcrete blocks. Indicating that the compressive strength of interlocking blocks is comparable to that of the conventional sandcrete blocks.

On the basis of the above, interlocking blocks provide a very good economic alternative to sandcrete blocks. Economically, it provides a cheaper means of construction, low cost resources (materials) and erection process. They therefore have the potential of supporting the affordable housing concept in Ghana. Interlocking blocks are also likely to support sustainable construction concept since they use materials that are locally abundant, less energy for their production and use, and make the interior part of the buildings cooler than sandcrete blocks.

\section{REFERENCES}

[1] Y. M. Adedeji, "Interlocking masonry: Panacea for sustainable low-cost housing in Nigeria," Pakistan Journal of Social Sciences, vol. 5, no. 8, pp. 744750, 2008.

[2] H. G. Harris, K. H. Oh and A. A. Hamid, "Development of new interlocking and mortarless block masonry units for efficient building system," in Proceedings of 6th Masonry Symposium, Saskatchewan, Canada, 1992.

[3] M. P. Amado, A. J. Pinto and C. V. Santos, "The sustainable building process," in Proceedings of XXXV IAHS World Congress on Housing Science, Melbourne, Australia, 2007.

[4] D. Chwieduk, "Towards sustainable energy buildings," Applied Energy, vol. 76, pp. 211-217,
2003.

[5] M. Calkins, Materials for sustainable sites: a complete guide to the evaluation, selection and use of sustainable construction materials, Hoboken, NJ, USA: John Wiley \& Sons, 2009.

[6] B. Ferguson, "A Value Chain Framework for Affordable Housing in Emerging Countries," Global Urban Development, vol. 4, no. 2, 2008.

[7] Raheem, A. A. ; Bello, O. A.; Makinde, O. A., "A comparative Study of cement and lime stabilized lateritic interlocking blocks," The Pacific Journal of Science and Technology, vol. 11, no. 2, pp. 27-34, 2010.

[8] Y. M. D. Adedeji, "Sustainable housing provision: preference for the use of interlocking masonry in housing delivery in Nigeria," Architecture Research, vol. 2, no. 5, pp. 81-86, 2012.

[9] M. Zakari and M. Akani, "Earthen construction, as a solution to building industries in Ghana," Journal of Economics and Sustainable Development, vol. 4, no. 3, pp. 190-198, 2013.

[10]S. Maini, "Earthen Architecture in the World," Auroville Earth Institute, 2010.

[11]R. Ashkin, "Innovative building technologies - the social housing angle," in Housing Africa 2013, Abuja, Nigeria, 2013.

[12]F. J. Fales, "Construction technology today and tomorrow," Glenwe/McGraw Hill, Peoria, 1991.

[13]H. Danso, "Building houses with locally available materials in Ghana: benefits and broblems," International Journal of Science and Technology, vol. 2, no. 2, pp. 225-231, 2013.

[14]P. Vanderwerf, "Mortarless Block Systems," Masonry Construction, vol. 12, no. 2, pp. 20-24, 1999.

[15]A. Serpell, A. Venturi and J. Contreras, Characterization of Waste in Building Construction Projects, L. Alarcon, Ed., Netherlands: A. A. Balkema, 1995.

[16]L. Koskela, "Application of the New Production Philosophy to Construction," CIFE, 1992.

[17] M. A. Nasly and A. A. M. Yassin , "Sustainable Housing Using an Innovative Interlocking Block Building System," in Proceedings of the Fifth National Conference on Civil Engineering (AWAM '09), Kuala Lumpur, Malaysia, 2009.

[18]A. K. Andam, "Bricks, blocks and the future administrative capital of Ghana," in A report delivered during the Inaugural lecture of the Ghana Academy of Arts and Sciences, Accra, Ghana, 2004.

[19]K. B. Anand and K. Ramamurthy, "Development and performance evaluation of interlocking block masonry," Journal of Architectural Engineering, vol. 6, no. 2, pp. 45-51, 2003.

[20] Y. M. D. Adedeji, "Materials preference options for sust ainable housing in selected cities in Nigeria," Akure, Nigeria, 2007.

[21] A. A. Raheem, A. K. Momoh and A. A. Soyingbe, "Comparative analysis of sandcrete hollow blocks and laterite interlocking blocks as walling elements," 
International Journal of Sustainable Construction Engineering \& Technology, vol. 3, no. 1, pp. 79-88, 2012.

[22]D. R. Ogunsemi, "The use of enough quality and quantity materials for building a durable edifice," in A Lecture delivered at Campus Transformation Network, Akure, Nigeria, 2010.

[23]H. Danso and D. Manu, "High cost of materials and land acquisition problems in the construction industry in Ghana," International Journal of Research in Engineering \& Applied Sciences (IJREAS), vol. 3, no. 3, pp. 18-33, 2013.

[24]M. D. Gidigasu, "Lateritic soil construction for housing in Ghana," The Journal of the Ghana Institution of Engineers, vol. 3, no. 2, pp. 19-38, 2005.

[25]D. E. Gooding and T. H. Thomas, "The potential of cement- stabilized building blocks as an urban building material in the developing countries," 1995.

[26] M. A. Ogunbiyi, R. A. Samson , F. A. Oginni and E. Akerele, "Comparative study of cement stabilized clay brick and sandcrete block as a building component," International Journal of Applied Science and Technology, vol. 4, no. 6, 2014.

[27]F. G. Bell, Engineering treatment of soil: soil stabilization, London, UK: E and FN SPON, 1993.

[28]J. P. Womack and D. T. Jones, Lean Thinking: Banish Waste and Create Wealth in your Corporation, New York, NY: Simon and Schuster, 1996, p. 350.

[29] O. Oluwole, J. Joshua and H. Nwagwo, "Finite element modeling of low heat conducting building bricks," Journal of Minerals and Materials Characterization and Engineering (JMMCE), vol. 11, pp. 800-806, 2012.

\section{BIOGRAPHIES}

S. Assiamah obtained his Bachelor of Technology degree in Building Technology from Sunyani Polytechnic, Sunyani, Ghana and Master's degree in Construction Management University of Education, Kumasi, Ghana. He is currently lecturing at building Technology department of Sunyani Polytechnic. His research areas are smart buildings, sustainable building and thermal properties of interlocking blocks.

Ing. H. Abeka obtained his Bachelor's degree in Civil Engineering from Kwame Nkrumah University of Science and Technology (KNUST), Kumasi, Ghana and Master's degree in Development Planning and Policy, and MPhil Structural Engineering from the same University. He is a Member of the Ghana Institution of Engineers (GhIE) and currently lecturing at civil engineering department of Sunyani Polytechnic. His research areas are urban planning and settlements, structural simulations and animations.
Engr. S. Agyeman obtained his Bachelor's degree in Geomatic Engineering from Kwame Nkrumah University of Science and Technology (KNUST), Kumasi, Ghana and Master's degree in Road and Transportation Engineering from the same University. He is a Member of the Institution of Engineering and Technology (IET), Ghana and currently lecturing at civil engineering department of Sunyani Polytechnic. His research areas are building permits, public transportation, traffic simulations and animations, and road traffic accidents analysis. 